\title{
AKIBAT HUKUM PENGKREDITAN PAJAK MASUKAN DENGAN \\ PAJAK KELUARAN DALAM \\ MASA PAJAK YANG TIDAK SAMA ${ }^{1}$
}

\author{
Evie Rachmawati Nur Ariyanti \\ Fakultas Hukum Universitas YARSI \\ Email: evie.rachmawati@yarsi.ac.id
}

\begin{abstract}
ABSTRAK
Pasal 9 Ayat (9) Undang-Undang Pajak Pertambahan Nilai membuka kemungkinan untuk mengkreditkan pajak masukan paling lambat 3 (tiga) bulan setelah akhir masa pajak saat pembuatan faktur pajak. Permasalahan timbul dalam hal faktur pajak diterima sudah melampaui jangka waktu yang telah ditetapkan. Ketentuan ini malah diatur dalam Penjelasan Pasal 9 Ayat (9). Ditinjau dari pembentukan peraturan perundang-undangan, penjelasan suatu pasal tidak boleh membuat norma baru karena bertentangan dengan Butir 177 Lampiran Undang-Undang Nomor 12 Tahun 2011 Tentang Pembentukan Peraturan Perundang-undangan. Selain itu juga tidak memenuhi asas kejelasan rumusan dalam pembentukan peraturan perundang-undangan yang baik dan materi muatannya tidak mencerminkan asas ketertiban dan kepastian hukum. Akibat hukum yang timbul terhadap wajib pajak yang melampaui batas waktu yang diperkenankan untuk mengkreditkan pajak masukan dengan pajak keluaran adalah selain membayar jumlah pajak yang tidak atau kurang dibayar, masih ditambah dengan pengenaan sanksi bunga dan kenaikan.
\end{abstract}

Kata kunci: PPN, Faktur pajak, Pajak Masukan

\section{PENDAHULUAN}

Pajak adalah pembayaran wajib yang dikenakan berdasarkan undangundang yang tidak dapat dihindari bagi yang berkewajiban dan bagi mereka yang tidak mau membayar pajak dapat dilakukan paksaan. Dengan demikian, maka akan terjamin bahwa kas negara selalu berisi uang pajak. Sebaliknya pengenaan pajak berdasarkan undang-undang akan menjamin bagi pembayar pajak adanya keadilan dan kepastian hukum sehingga pemerintah tidak dapat sewenang-wenang menetapkan besarnya pajak. $^{2}$

Setelah amandemen Undang-Undang Dasar Negara Republik Indonesia Tahun 1945, ketentuan mengenai pajak mengalami perubahan yang sangat

\footnotetext{
1 Artikel ini merupakan bagian dari Laporan Penelitian yang didanai oleh Yayasan YARSI Tahun Akademik 2018/2019

${ }^{2}$ Marihot Pahala Siahaan, Bea Meterai di Indonesia, (Jakarta: PT. Raja Grafindo Persada, 2006), hal.7
} 
prinsipil. Hal ini dapat dilihat pada Pasal 23A yang mengatur bahwa pajak dan pungutan yang bersifat memaksa untuk keperluan negara diatur dengan undang-undang. Pasal 23A UUD 1945 tetap melanjutkan asas legalitas yang awalnya dari Pasal 23 Ayat (2) UUD 1945 sebelum amandemen. Sekalipun demikian, terdapat perubahan yang prinsipil karena bukan hanya pajak melainkan pungutan yang bersifat memaksa harus pula diatur dengan undang-undang. Hal ini merupakan perkembangan positif agar tidak sewenang-wenang membebankan pungutan yang bersifat memaksa kepada warga negara tanpa diatur dengan undang-undang sebagai perwujudan dari negara hukum.

Pasal 23A UUD 1945 telah diwujudkan dalam bentuk Undang-undang Pajak dengan kedudukannya untuk mengganti maupun mengubah Undang-undang Pajak. Adapun sebagai Undang-undang Pajak dalam kedudukannya sebagai pengganti adalah sebagai berikut: ${ }^{3}$

a. Undang-Undang Nomor 14 Tahun 2002 Tentang Pengadilan Pajak terhadap Undang-Undang Nomor 17 Tahun 1997 Tentang Badan Penyelesaian Sengketa Pajak;

b. Undang-Undang Nomor 28 Tahun 2009 Tentang Pajak Daerah dan Retribusi Daerah terhadap Undang-Undang Nomor 18 Tahun 1997 Tentang Pajak Daerah dan Retribusi Daerah sebagaimana telah diubah dengan Undang-Undang Nomor 34 Tahun 2000.

Sementara itu, Undang-Undang Pajak dalam kedudukannya sebagai pengubah adalah sebagai berikut: ${ }^{4}$

a. Undang-Undang Nomor 17 Tahun 2006 Tentang Perubahan Atas Undang-Undang Nomor 10 Tahun 1995 Tentang Kepabeanan;

b. Undang-Undang Nomor 39 Tahun 2007 Tentang Perubahan Undang-Undang Nomor 11 Tahun 2007 Tentang Cukai;

c. Undang-Undang Nomor 28 Tahun 2007 Tentang Perubahan Ketiga Atas Undang-Undang Nomor 6 Tahun 1983 Tentang Ketentuan Umum dan Tata Cara Perpajakan;

${ }^{3}$ M. DjafarSaidi, PembaruanHukumPajak, (Jakarta: PT. Raja GrafindoPersada, 2011), ${ }^{4}$ Ibid, hal. 10 
d. Undang-Undang Pajak Penghasilan Nomor 36 Tahun 2008 Tentang Perubahan Ketiga Atas Undang-Undang Nomor 7 Tahun 1983 Tentang Pajak Penghasilan;

e. Undang-Undang Nomor 42 Tahun 2009 Tentang Perubahan Ketiga Atas Undang-Undang Nomor 8 Tahun 1983 Tentang Pajak Pertambahan Nilai Barang Dan Jasa Dan Pajak Penjualan Atas Barang Mewah.

Pajak Pertambahan Nilai (PPN) mulai berlaku di Indonesia sejak 1 April 1985. Undang-Undang yang mengaturnya telah 3 (tiga) kali diubah, yaitu: a. mulai 1 Januari 1995 dilakukan perubahan pertama dengan UU Nomor 11 Tahun 1994 meliputi Pasal 1 sampai dengan Pasal 17 berurutan;

b. mulai 1 Januari 2001 dilakukan perubahan kedua dengan UU Nomor 18 Tahun 2000 meliputi Pasal 1 sampai dengan Pasal 16C namun tidak berurutan; dan

c. mulai 1 April 2010 dilakukan perubahan ketiga dengan UU Nomor 42 Tahun 2009 meliputi Pasal 1 sampai dengan Pasal 16D namun tidak berurutan.

PPN merupakan salah satu jenis pajak pusat. PPN memiliki tarif pajak yang dapat digunakan untuk menentukan timbulnya pajak yang terutang sebagai kewajiban Pengusaha Kena Pajak (PKP). Tarif PPN sebesar 10\% (sepuluh persen) sebagaimana diatur pada Pasal 7 Ayat (1) UU PPN. Tarif PPN ini dapat dibah menjadi paling rendah 5\% (lima persen) dan paling tinggi 15\% (lima belas persen) yang perubahannya diatur dengan Peraturan Pemerintah. Sementara itu, tarif PPN sebesar 0\% (nol persen) diterapkan pada ekspor barang kena pajak berwujud, ekspor barang kena pajak tidak berwujud, dan ekspor jasa kena pajak. Pajak yang terutang dihitung dengan cara mengalikan tarif yang diatur dalam Pasal 7 UU PPN dengan Dasar Pengenaan Pajak (DPP).

Penghitungan PPN yang akan disetor ke kas negara menggunakan metode pengurangan tidak langsung (credit method/invoice method/indirect substraction method). Mekanisme ini dalam dalam UU PPN 1984 disebut dengan mekanisme pengkreditan. Dalam metode pengkreditan dikenal adanya pajak yang dibayar pada saat perolehan Barang Kena Pajak (BKP) atau Jasa Kena Pajak (JKP) dan pajak yang dipungut pada saat penyerahan BKP atau JKP. Pajak yang dibayar pada saat perolehannya dinamakan pajak masukan (input tax), sebaliknya pajak yang 
dipungut dinamakan pajak keluaran (output tax). Jumlah PPN yang wajib disetor ke kas negara adalah selisih lebih pajak keluaran dengan pajak masukan. Jika jumlah pajak masukan lebih besar daripada jumlah pajak keluaran, maka yang terjadi bukannya menyetor pajak ke kas negara melainkan sebaliknya, Pengusaha Kena Pajak (PKP) berhak minta pengembalian dari kas negara.

Prinsip dasar pengkreditan pajak masukan yang dianut oleh UU PPN 1984 adalah pengkreditan dalam masa pajak yang sama. Namun prinsip dasar ini hanya dapat dilakukan secara konsisten dalam hal faktur pajak selalu diterima tepat waktu oleh PKP Pembeli BKP atau Penerima JKP. Faktur pajak diterima tepat waktu pada umumnya apabila UU PPN menganut basis kas (cash basis). Namun berdasarkan Pasal 11 Ayat (1) UU PPN 1984 menganut basis akrual (accrual basis) ketika menentukan pajak terutang. Ketika menerapkan basis akrual ini, maka yang terjadi adalah bukannya PKP Pembeli atau Penerima JKP selalu menerima faktur pajak tepat waktu, melainkan sebaliknya seringkali terlambat. Dalam hal faktur pajak diterima terlambat oleh PKP Pembeli BKP atau Penerima JKP, maka tidak mungkin lagi dikreditkan dengan pajak keluaran dalam masa pajak yang sama.

Pasal 9 Ayat (9) UU PPN membuka kemungkinan untuk mengkreditkan pajak masukan paling lambat 3 (tiga) bulan setelah akhir masa pajak saat pembuatan faktur pajak. Permasalahan timbul dalam hal faktur pajak diterima sudah melampaui jangka waktu yang telah ditetapkan. Misalnya faktur pajak tertanggal 26 Januari 2018 baru diterima oleh PKP Pembeli BKP atau Penerima JKP pada tanggal 26 Mei 2018. Pasal 9 Ayat (9) UU PPN tidak mengatur kemungkinan pengkreditan pajak masukan yang diterima melampaui jangka waktu 3 (tiga) bulan sejak akhir pembuatan faktur pajak. Namun demikian, ternyata permasalahan ini diselesaikan melalui memori penjelasan Pasal 9 Ayat (9) yang mengatur bahwa dalam hal batas waktu tersebut telah dilampaui, maka pengkreditan pajak masukan dapat dikreditkan dengan cara pembetulan SPT Masa PPN yang bersangkutan. Padahal, sesuai dengan konsep pembentukan peraturan perundang-undangan (legal drafting), penjelasan suatu pasal tidak boleh memuat norma baru. Bertitik tolak dari uraian tersebut di atas, penelitian ini hendak 
mengkaji tentang akibat hukum pengkreditan pajak masukan dengan pajak keluaran dalam masa pajak yang tidak sama.

Bertitik tolak dari uraian tersebut di atas, pertanyaan dalam penelitian adalah sebagai berikut:

a. Bagaimana regulasi pengkreditan pajak masukan dengan pajak keluaran dalam masa pajak yang tidak sama ditinjau dari pembentukan peraturan perundang-undangan di Indonesia?

b. Bagaimana akibat hukum yang timbul terhadap Wajib Pajak yang melampaui batas waktu yang diperkenankan untuk mengkreditkan pajak masukan dengan pajak keluaran?

\section{TINJAUAN PUSTAKA}

Pajak Pertambahan Nilai merupakan pajak tidak langsung. Karakter ini memberikan konsekuensi yuridis bahwa antara pemikul beban pajak (destinataris pajak) dengan penanggung jawab atas pembayaran pajak ke kas negara berada pada pihak yang berbeda. Pemikul beban pajak ini secara nyata berkedudukan sebagai Pembeli BKP atau Penerima JKP, sedangkan penanggung jawab atas pembayaran pajak ke kas negara adalah PKP yang bertindak sebagai Penjual BKP atau Pengusaha JKP. Oleh karena itu, apabila terjadi penyimpangan pemungutan PPN, Administrasi pajak (fiskus) akan meminta pertanggungjawaban kepada Penjual BKP atau Pengusaha JKP tersebut, bukan kepada pembeli, walaupun pembeli kemungkinan juga berstatus sebagai PKP. Digolongkannya PPN sebagai pajak tidak langsung didasarkan pada 2 (dua) sudut pandang sebagai berikut: ${ }^{5}$

a. Sudut pandang ekonomi, beban pajak dialihkan kepada pihak lain, yaitu pihak yang akan mengkonsumsi barang atau jasa yang menjadi objek pajak;

b. Sudut pandang yuridis, tanggung jawab pembayaran pajak kepada kas negara tidak berada di tangan pihak yang memikul beban pajak. Sudut pandang secara yuridis ini membawa konsekuensi filosofis bahwa dalam pajak tidak langsung apabila pembeli atau penerima jasa telah membayar pajak yang tidak terutang kepada penjual atau pengusaha jasa, pada hakekatnya sama dengan telah membayar pajak tersebut ke kas negara.

${ }^{5}$ Untung Sukardji, Pajak Pertambahan Nilai, (Jakarta: PT. Raja GrafindoPersada, 2015), 
Menurut Sukardji, tidak pernah ada nama UU PPN Tahun 1994 atau UU PPN 2000 dan tidak akan ada UU PPN Tahun 2009. Jadi, meskipun sudah 3 (tiga) kali diubah, Undang-Undang Nomor 8 Tahun 1983 Tentang Pajak Pertambahan Nilai Barang Dan Jasa Dan Pajak Penjualan Atas Barang Mewah, namanya tetap UU Pajak Pertambahan Nilai (PPN) 1984. Hal ini disebabkan: ${ }^{6}$

a. Dari tiga kali perubahan ternyata tidak pernah mengubah Pasal 20 padahal dalam Pasal ini ditentukan bahwa nama UU Nomor 8 Tahun 1983 adalah UU PPN 1984;

b. Baik UU Nomor 11 Tahun 1994 maupun UU Nomor 18 Tahun 2000 tidak pernah menggantikan kedudukan UU Nomor 8 Tahun 1983 yang tercermin dari Pasal III UU Nomor 11 Tahun 1994 dan Pasal II UU Nomor 18 Tahun 2000;

c. Adapun UU Nomor 42 tahun 2009 tidak menetapkan nama dari undang-undang ini karena dalam perubahan ketiga ini selain tidak mengubah Pasal 20 UU Nomor 8 Tahun 1983, juga tidak mencabut eksistensi UU Nomor 8 tahun 1983 sehingga sama halnya dengan undang-undang tentang perubahan sebelumnya, undang-undang ini tidak menggantikan kedudukan UU Nomor 8 Tahun 1983.

Sejak tahun 1983, hukum nasional di bidang perpajakan telah menunjukkan jati dirinya karena telah memiliki hukum (baca: undang-undang) sendiri dengan tidak lagi menggunakan perundang-undangan peninggalan kolonial Belanda. Politik hukum yang dibangun bangsa Indonesia khususnya di bidang perpajakan paling tidak telah menunjukkan adanya proses pembangunan hukum yang berintikan pada pembentukan dan pembaruan terhadap materi-materi hukum agar dapat sesuai dengan kebutuhan yang dihadapi bangsa Indonesia, serta adanya pelaksanaan dan penegasan fungsi lembaga dan pembinaan para penegak hukum terhadap proses penerapan UU yang ada. ${ }^{7}$

Undang-Undang tentang pembentukan peraturan perundang-undangan merupakan pelaksanaan Pasal 22A Undang-Undang Dasar Negara Republik

\footnotetext{
${ }^{6}$ UntungSukardji, Undang-Undang PPN 1984 SetelahPerubahanKetigaDenganUndangUndangNomor 42 tahun 2009 KomentarPasal Demi Pasal, (Jakarta: PT. Raja GrafindoPersada, 2010), hal 21-22

${ }^{7}$ Wirawan B. Ilyas dan Richard Burton, Hukum Pajak Edisi 5, (Jakarta: Salemba Empat, 2011), hal. 16
} 
Indonesia Tahun 1945 yang menegaskan bahwa ketentuan lebih lanjut mengenai tata cara pembentukan undang-undang diatur lebih lanjut dengan undang-undang. Perintah tersebut telah dilaksanakan yakni dengan diberlakukannya Undang-Undang Nomor 10 Tahun 2004 tentang Pembentukan Peraturan Perundang-undangan yang kemudian dalam perkembangannya diganti dengan Undang-Undang Nomor 12 Tahun 2011 Tentang Pembentukan Peraturan Perundang-undangan.

Pengonsepan atau hukum perancangan (legal drafting) adalah cara penyusunan rancangan peraturan sesuai tuntutan teori, asas dan kaidah perancangan peraturan perundang-undangan. Lembaga yang wajib membentuk peraturan baik lingkup nasional maupun lingkup daerah, perlu menerapkan prinsip-prinsip legal drafting secara taat asas. ${ }^{8}$ Pada saat melakukan perubahan yang ketiga terhadap UU PPN, seharusnya DPR selaku lembaga legislatif yang sudah menguasai teknik pembuatan undang-undang, mengambil inisiatif untuk memperbaiki kekeliruan yang terjadi dalam Pasal 9 Ayat (9) khususnya pada bagian penjelasan. Bagian penjelasan menurut teori pengonsepan atau hukum perancangan (legal drafting) seharusnya tidak diperbolehkan membuat norma baru. Jika hal ini dibiarkan dapat menimbulkan ketidakpastian hukum. Pelaksanaan undang-undang seharusnya memberi rasa keadilan kepada masyarakat, bukan justru sebaliknya, yaitu menimbulkan keresahan.

Pihak yang membuat konsep penyusunan rancangan peraturan (legal drafter) harus sungguh-sungguh memperhatikan asas pembentukan peraturan perundang-undangan yang baik yang meliputi:

a. Asas kejelasan tujuan, yaitu bahwa setiap pembentukan peraturan perundang-undangan harus mempunyai tujuan yang jelas yang hendak dicapai;

b. Asas kelembagaan atau organ pembentuk yang tepat, yaitu bahwa setiap jenis peraturan perundang-undangan harus dibuat oleh lembaga/pejabat pembentuk peraturan perundang-undangan yang berwenang;

c. Asas kesesuaian antara jenis dan materi muatan, yaitu dalam pembentukan peraturan perundang-undangan harus benar-benar memperhatikan materi muatan yang tepat dengan jenis peraturan perundang-undangannya;

8 Supardan Modeong dan Zudan Arif Fakrulloh, Legal Drafting Berporos Hukum Humanis Partisipatoris, (Jakarta: PT . Perca, 2005), hal. 13 
d. Asas dapat dilaksanakan, yaitu setiap pembentukan peraturan perundang-undangan harus memperhitungkan efektivitas peraturan perundang-undangan tersebut dalam masyarakat baik secara filosofis, yuridis, maupun sosiologis;

e. Asas kedayagunaan dan kehasilgunaan, yaitu setiap peraturan perundang-undangan dibuat karena memang benar-benar dibutuhkan dan bermanfaat dalam mengatur kehidupan bermasyarakat, berbangsa, dan bernegara;

f. Asas kejelasan rumusan, yaitu setiap peraturan perundang-undangan harus memenuhi persyaratan teknis penyusunan peraturan perundang-undangan, sistematika dan pilihan kata atau terminologi, serta bahasa hukumnya jelas dan mudah dimengerti sehingga tidak menimbulkan berbagai macam interpretasi dalam pelaksanaannya;

g. Asas keterbukaan, yaitu dalam proses pembentukan peraturan perundang-undangan mulai dari perencanaan, persiapan, penyusunan dan pembahasan seluruh lapisan masyarakat perlu diberi kesempatan yang seluasluasnya untuk mengetahui dan memberikan masukan dalam proses pembuatan peraturan perundang-undangan agar peraturan yang terbentuk menjadi populis dan efektif.

\section{METODE PENELITIAN}

\section{Jenis Penelitian}

Ditinjau dari sudut tujuan, penelitian hukum dibagi menjadi dua jenispenelitian, yaitu penelitian hukum normatif dan penelitian hukum sosiologis atauempiris. ${ }^{9}$ Penelitian hukum normatif dapat dibatasi pada penggunaan studidokumen atau bahan pustaka saja, yaitu pada data sekunder. ${ }^{10}$ Penelitian ini termasuk dalam penelitian hukum normatif.

\section{Rancangan Penelitian}

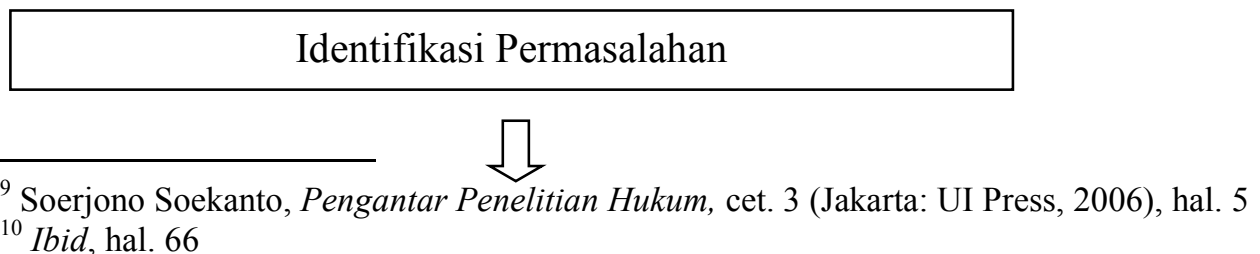




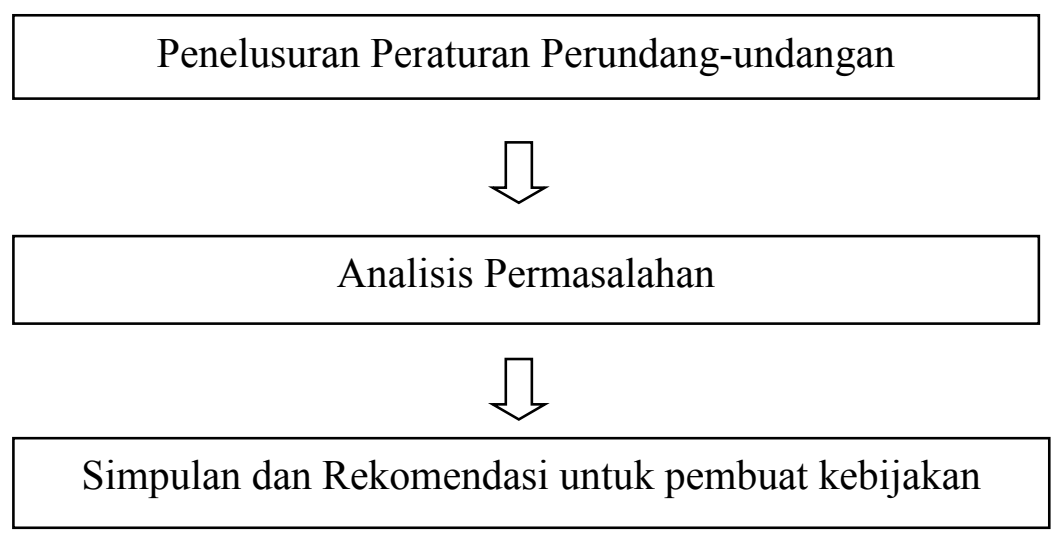

\section{Cara Penetapan dan Sampel Penelitian}

Populasi penelitian ini adalah hukum positif terkait pajak masukan dan pajak keluaran di Indonesia. Sample ditetapkan dengan pemilihan sampel yang bertujuan (purposive sampling). Sampel penelitiannya adalah peraturan perundang-undangan yang terkait dengan pajak masukan dan pajak keluaran.

\section{Jenis Data}

Dalam penelitian pada umumnya dibedakan antara data yang diperoleh langsung dari masyarakat dan dari bahan-bahan pustaka. Bahan yang diperoleh langsung dari masyarakat dinamakan data primer (atau data kasar), sedangkan yang diperoleh dari bahan pustaka lazimnya dinamakan data sekunder. ${ }^{11}$ Jenis data dalam penelitian ini adalah data sekunder. Data sekunder yang digunakan adalah sebagai berikut:

1. Bahan hukum primer, yaitu bahan hukum yang mengikat terdiri dari:
a. Undang-Undang Dasar Negara Republik Indonesia Tahun1945;
b. Undang-Undang Nomor 12 Tahun 2011 Tentang Pembentukan Peraturan Perundang-undangan;
c. Undang-Undang Nomor 16 Tahun 2009 Tentang Perubahan Keempat Atas Undang-Undang Nomor 6 Tahun 1983 Tentang Ketentuan Umum dan Tata Cara Perpajakan;

11 Soerjono Soekanto dan Sri Mamudji, Penelitian Hukum Normatif Suatu Tinjauan Singkat, (Jakarta: PT Raja Grafindo Persada, 2001), hal. 12 
d. Undang-Undang Nomor 42 Tahun 2009 Tentang Perubahan Ketiga Atas Undang-Undang Nomor 8 Tahun 1983 Tentang Pajak Pertambahan Nilai dan Pajak Penjualan Atas Barang Mewah.

2. Bahan hukum sekunder, yaitu bahan-bahan hukum isinya menjelaskan mengenai bahan hukum primer berupa buku dan artikel yang berkaitan dengan masalah yang diteliti.

3. Bahan hukum tersier, yaitu bahan yang memberikan petunjuk maupun informasi tentang bahan hukum primer dan bahan hukum sekunder seperti kamus yang berhubungan dengan penelitian ini.

\section{Instrumen Pengumpulan Data}

Penelitian hukum normatif adalah penelitian kepustakaan sehingga pengumpulan datanya adalah dengan melakukan studi kepustakaan.

\section{Analisis Data}

Analisis data dilakukan secara deskriptif analitis. Data yang terkumpul selanjutnya diolah, disistematisir sesuai dengan urutan permasalahan dan dianalisis. Data yang diperoleh disajikan secara kualitatif.

\section{HASIL PENELITIAN}

Regulasi Pengkreditan Pajak Masukan dengan Pajak Keluaran dalam Masa Pajak yang Tidak Sama Ditinjau dari Pembentukan Perundang-undangan di Indonesia

Pada saat ini pengkreditan pajak masukan dengan pajak keluaran masih diatur dalam Pasal 9 Undang-Undang Nomor 42 Tahun 2009 Tentang Perubahan Ketiga Atas Undang-Undang Nomor 8 Tahun 1983 Tentang Pajak Pertambahan Nilai dan Pajak Penjualan Atas Barang Mewah. Pasal 9 UU PPN ini awalnya hanya 8 (delapan) ayat saja. Penambahan terjadi ketika dilakukan perubahan pertama pada tahun 1994. Pasal 9 Ayat (8) yang semula hanya sampai dengan huruf c ditambah sampai dengan huruf i. Selain itu, Pasal 9 yang semula 8 (delapan) ayat ditambah menjadi 14 (empat belas) ayat. 
Ketentuan yang tercantum dalam Pasal 9 Ayat (9) UU PPN diadaptasi dari Pasal 18 Peraturan Pemerintah Nomor 22 Tahun 1985 Tentang Pelaksanaan Pajak Pertambahan Nilai 1984 yang mengatur bahwa pengkreditan pajak masukan dengan pajak keluaran dalam masa pajak yang tidak sama hanya dimungkinkan atas persetujuan Direktur Jenderal Pajak. Hal ini dilakukan untuk mengisi kekosongan hukum karena pada ayat sebelumnya yaitu Pasal 9 Ayat (2) UU PPN hanya mengatur prinsip bahwa pajak masukan dalam suatu masa pajak dapat dikreditkan dengan pajak keluaran untuk masa pajak yang sama. Pasal 9 Ayat (2) ini justru diubah pada saat terjadi perubahan yang kedua pada tahun 2000. Perubahan tersebut menghilangkan kata "dapat dikreditkan" menjadi “dikreditkan".

Menurut Yani, norma "dapat" berkonsekuensi pada ambiguitas sebuah aturan karena artinya bisa dilaksanakan, bisa juga tidak dilaksanakan. Sebaliknya, penghilangan kata dapat akan berkonsekuensi pada kewajiban prosedural. ${ }^{12} \mathrm{UU}$ PPN ini tidak mengantisipasi bahwa prinsip pengkreditan dalam masa pajak yang sama tidak serasi dibandingkan dengan basis akrual yang diadopsi dalam Pasal 11 Ayat (1) UU PPN dalam hal faktur pajak terlambat diterima. Prinsip akrual ini tertuang dalam Penjelasan Pasal 11 Ayat (1) UU PPN sebagai berikut:

"Pemungutan Pajak Pertambahan Nilai dan Pajak Penjualan Atas Barang Mewah menganut prinsip akrual, artinya terutangnya pajak terjadi pada saat penyerahan Barang kena Pajak atau pada saat penyerahan penyerahan Jasa Kena Pajak, meskipun pembayaran atas penyerahan tersebut belum diterima atau belum sepenuhnya diterima atau pada saat impor Barang Kena Pajak. Satt terutanya pajak untuk transaksi yang dilakukan melalui "electronic commerce" tunduk pada ayat ini".

Materi Pasal 9 Ayat (9) tetap bertahan sampai dengan UU PPN mengalami perubahan yang ketiga kalinya sebagai berikut:

"Pajak Masukan yang dapat dikreditkan tetapi belum dikreditkan dengan Pajak Keluaran pada Masa Pajak yang sama, dapat dikreditkan pada Masa Pajak berikutnya paling lambat 3 (tiga) bulan setelah berakhirnya Masa Pajak yang bersangkutan sepanjang belum dibebankan sebagai biaya dan belum dilakukan pemeriksaan".

${ }^{12}$ Ahmad Yani, Pembentukan Peraturan Perundang-Undangan yang Responsif, (Jakarta: Penerbit Konpress, 2013), hal. 95 
Begitu pula dengan Penjelasan Pasal 9 Ayat (9) yang juga tidak mengalami perubahan sebagai berikut:

"Ketentuan ini memungkinkan Pengusaha Kena Pajak untuk mengkreditkan Pajak Masukan dengan Pajak Keluaran dalam Masa Pajak yang tidak sama yang disebabkan, antara lain, Faktur Pajak terlambat diterima. Pengkreditan Pajak Masukan dalam Masa Pajak yang tidak sama tersebut hanya diperkenankan dilakukan pada Masa Pajak berikutnya paling lama 3 (tiga) bulan setelah berakhirnya Masa Pajak yang bersangkutan. Dalam hal jangka waktu tersebut telah dilampaui, pengkreditan Pajak Masukan tersebut dapat dilakukan melalui pembetulan Surat Pemberitahuan Masa Pajak Pertambahan Nilai yang bersangkutan. Kedua cara pengkreditan tersebut hanya dapat dilakukan apabila Pajak Masukan yang bersangkutan belum dibebankan sebagai biaya atau tidak ditambahkan (dikapitalisasi) kepada harga perolehan Barang Kena Pajak atau Jasa Kena Pajak yang bersangkutan dan terhadap Pengusaha Kena Pajak belum dilakukan pemeriksaan".

Jika ditinjau dari pembentukan peraturan perundang-undangan, bagian Penjelasan Pasal 9 Ayat (9) inilah yang justru dipermasalahkan karena membuat aturan baru dalam hal terjadinya pengkreditan pajak masukan dengan pajak keluaran yang faktur pajaknya diterima lebih dari 3 (tiga) bulan. Padahal dalam bagian batang tubuhnya hanya mengatur bahwa pengkreditan pajak masukan dengan pajak keluaran dapat dilakukan dalam masa pajak yang tidak sama paling lambat 3 (tiga) bulan saja. Penjelasan Pasal 9 Ayat (9) UU PPN ini tidak sesuai dengan Butir 177 Lampiran II Teknik Penyusunan Peraturan Perundang-undangan dari Undang-Undang Nomor 12 Tahun 2011 Tentang Pembentukan Peraturan Perundang-undangan yang mengatur bahwa penjelasan tidak dapat digunakan sebagai dasar hukum untuk membuat peraturan lebih lanjut dan tidak boleh mencantumkan rumusan yang berisi norma.

UU ini menggantikan Undang-Undang Nomor 10 Tahun 2004 Tentang Pembentukan Peraturan Perundang-undangan yang sebelumnya menjadi pedoman yuridis dalam pembentukan suatu perundang-undangan. Perbaikan sekaligus penyempurnaan terhadap UU sebelumnya dilakukan baik secara teknis maupun materi muatannya seperti:

a. Penambahan Ketetapan MPR sebagai salah satu jenis peraturan perundang-undangan dan hierarkinya setelah UUD NRI Tahun 1945; 
b. Perluasan cakupan perencanaan peraturan perundang-undangan yang tidak hanya untuk Prolegnas dan Prolegda melainkan juga perencanaan Peraturan Pemerintah, Peraturan Presiden, dan Peraturan Perundang-undangan lainnya;

c. Pengaturan mekanisme pembahasan Rancangan Undang-Undang tentang pencabutan Peraturan Pemerintah Pengganti Undang-Undang;

d. Pengaturan Naskah Akademik sebagai suatu persyaratan dalam penyusunan Rancangan Undang-Undang atau Rancangan Peraturan Daerah Provinsi dan Rancangan Peraturan Daerah Kabupaten/Kota;

e. Mekanisme penyampaian hak masyarakat, baik orang perseorangan maupun kelompok orang yang mempunyai kepentingan atas substansi rancangan peraturan perundang-undangan, untuk memberikan masukan secara lisan dan/ atau tertulis dalam pembentukan peraturan perundang-undangan;

f. Pengaturan mengenai keikutsertaan Perancang Peraturan Perundang-perundangan, peneliti, dan tenaga ahli dalam tahapan Pembentukan Peraturan Perundang-undangan;

g. Penambahan teknik penyusunan Naskah Akademik dalam Lampiran I Undang-Undang ini.

Menurut Yani, teknik penyusunan peraturan perundang-undangan merupakan pedoman teknis yang harus diikuti dalam penyusunan peraturan perundang-undangan. ${ }^{13}$ Materi Pasal 9 Ayat (9) beserta Penjelasannya ini juga diabaikan begitu saja ketika UU PPN mengalami perubahan yang kedua pada tahun 2000 dan perubahan yang ketiga pada tahun 2009. Seharusnya ketika UU PPN diubah ketiga kalinya pada tahun 2009, pada saat itulah sebenarnya waktu yang tepat bagi tim perumus untuk menyesuaikan dengan Butir 150 Lampiran Sistematika Teknik Penyusunan Peraturan Perundang-undangan dari Undang-Undang Nomor 10 Tahun 2004 Tentang Pembentukan Peraturan Perundang-undangan yang mengatur bahwa penjelasan tidak dapat digunakan sebagai dasar hukum untuk membuat peraturan lebih lanjut. UU ini mengingatkan untuk menghindari membuat rumusan norma di dalam bagian penjelasan.

Pasal 1 Angka 1 Undang-Undang Nomor 12 Tahun 2011 Tentang Pembentukan Peraturan Perundang-undangan memberikan definisi bahwa yang

${ }^{13}$ Ibid, hal. 40 
dimaksud pembentukan peraturan perundang-undangan adalah pembuatan peraturan perundang-undangan yang mencakup tahapan perencanaanm penyusunan, pembahasan, pengesahan atau penetapan, dan pengundangan. Pada saat membentuk peraturan perundang-undangan harus dilakukan berdasarkan pada asas pembentukan peraturan perundangan-undangan yang baik. Ditinjau dari pembentukan perundang-undangan, maka Pasal 9 Ayat (9) dan Penjelasannya tidak memenuhi asas pembentukan peraturan perundang-undangan yang baik, yakni asas kejelasan rumusan seperti yang diatur dalam Pasal 5 Huruf $\mathrm{f}$ Undang-Undang Nomor 12 Tahun 2011 Tentang Pembentukan Peraturan Perundang-undangan. Asas ini pun juga sudah diatur dalam UU sebelumnya. Jadi, setiap peraturan perundang-undangan harus memenuhi persyaratan teknis penyusunan peraturan perundang-undangan, sistematika dan pilihan kata atau terminologi, serta bahasa hukumnya jelas dan mudah dimengerti sehingga tidak menimbulkan berbagai macam interpretasi dalam pelaksanaannya.

Menurut Farida, asas-asas pembentukan peraturan perundang-undangan yang baik adalah suatu pedoman atau suatu rambu-rambu dalam pembentukan peraturan perundang-undangan yang baik. ${ }^{14}$ Selain rumusan pasal berpijak pada asas formal, juga berpedoman pada asas materiil seperti yang diatur dalam Pasal 6 Ayat (1) Undang-Undang Nomor 12 Tahun 2011 Tentang Pembentukan Peraturan Perundang-undangan berikut ini:

"Materi muatan peraturan perundang-undangan harus mencerminkan asas:
a. Pengayoman;
b. Kemanusiaan;
c. Kebangsaan;
d. Kekeluargaan;
e. Kenusantaraan;
f. bhinneka tunggal ika;
g. keadilan;
h. kesamaan kedudukan dalam hukum dan pemerintahan;
i. ketertiban dan kepastian hukum; dan/ atau
j. keseimbangan, keserasian, dan keselarasan".

Berdasarkan ketentuan tersebut, maka Pasal 9 Ayat (9) dan Penjelasannya tidak sesuai dengan asas ketertiban dan kepastian hukum karena setiap materi muatan peraturan perundang-undangan harus mewujudkan ketertiban dalam

\footnotetext{
${ }^{14}$ Maria Farida, Ilmu Perundang-undangan (1), (Yogyakarta: Kanisius, 2007), hal. 252
} 
masyarakat melalui jaminan kepastian hukum. Bagaimana mengandung kepastian hukum jika hal yang sangat krusial tidak diatur dalam batang tubuh atau Pasalnya namun hanya diatur dalam penjelasannya yang jelas-jelas bertentangan dengan teknik penyusunan peraturan perundang-undangan. Bukankah hal ini mengingatkan kita ketika Panitia Ad-Hoc III melakukan amandemen terhadap Undang-Undang Dasar 1945. Mereka sepakat untuk meniadakan bagian Penjelasan dengan mengangkat hal-hal yang bersifat normatif dalam pasal-pasalnya.

\section{Akibat Hukum yang Timbul Terhadap Wajib Pajak yang Melampaui Batas Waktu yang Diperkenankan untuk Mengkreditkan Pajak Masukan dengan Pajak Keluaran}

Setiap undang-undang perpajakan terdapat hukum pajak materiil dan formil, baik yang diatur tersendiri maupun yang menggabungkan keduanya dalam satu undang-undang. Meski demikian, hukum pajak materiil dan formil merupakan satu kesatuan yang berjalan berdampingan walaupun dibentuk dalam undang-undang yang terpisah. ${ }^{15}$ Hukum pajak materiil adalah peraturan perundangan perpajakan yang mengatur tentang subjek, objek, dan tarif pajak untuk masing-masing jenis pajak. ${ }^{16}$ Hukum pajak formil merupakan peraturan-peraturan perundang-undangan tentang cara bagaimana hukum pajak materiil menjadi kenyataan. ${ }^{17}$

Pengaturan hukum pajak materiil dalam undang-undang tersendiri adalah sebagai berikut:

a. Undang-Undang Nomor 36 Tahun 2008 Tentang Perubahan Keempat Atas Undang-Undang Nomor 7 Tahun 1983 Tentang Pajak Penghasilan;

b. Undang-Undang Nomor 42 Tahun 2009 Tentang Perubahan Ketiga Atas Undang-Undang Nomor 8 Tahun 1983 Tentang Pajak Pertambahan Nilai Barang dan Jasa dan Pajak Penjualan Atas Barang Mewah;

c. Undang-Undang Nomor 13 Tahun 1985 Tentang Bea Meterai.

\footnotetext{
${ }^{15}$ M. Farouq, Hukum Pajak di Indonesia, (Jakarta: Prenada Media Grup, 2018), hal 386

${ }^{16}$ Bustamar Ayza, Hukum Pajak Indonesia, (Depok: Penerbit Kencana, 2017) hal. 108

${ }^{17}$ Ibid, hal. 159
} 
Pengaturan hukum pajak formil dalam undang-undang tersendiri adalah sebagai berikut:

a. Undang-Undang Nomor 6 Tahun 1983 Tentang Ketentuan Umum dan Tata Cara Perpajakan Sebagaimana Telah Beberapa Kali Diubah Terakhir Dengan Undang-Undang Nomor 16 Tahun 2009 (selanjutnya disebut dengan UU KUP);

b. Undang-undang Nomor 19 Tahun 2000 Tentang Perubahan Atas Undang-Undang Nomor 19 Tahun 1997 Tentang Penagihan Pajak Penghasilan dengan Surat Paksa;

c. Undang-Undang Nomor 14 Tahun 2002 Tentang Pengadilan Pajak .

Pengaturan hukum pajak materiil dan formil dalam satu undang-undang adalah sebagai berikut:

a. Undang-Undang Nomor 20 Tahun 2000 Tentang Perubahan Atas Undang-Undang Nomor 21 Tahun 1997 Tentang Bea Perolehan Hak atas Tanah dan Bangunan;

b. Undang-Undang Nomor 12 Tahun 1994 Tentang Perubahan Atas Undang-Undang Nomor 12 Tahun 1985 Tentang Pajak Bumi dan Bangunan;

c. Undang-Undang Nomor 39 Tahun 2007 Tentang Perubahan Atas Undang-Undang Nomor 11 Tahun 1995 Tentang Cukai;

d. Undang-Undang Nomor 17 Tahun 2006 Tentang Perubahan Atas Undang-Undang Nomor 10 Tahun 1995 Tentang Kepabeanan;

e. Undang-Undang Nomor 28 Tahun 2009 Tentang Pajak Daerah dan Retribusi Daerah.

Pajak Masukan yang belum dikreditkan dengan Pajak Keluaran pada Masa Pajak yang sama, dapat dikreditkan pada Masa Pajak berikutnya paling lama 3 (tiga) bulan setelah berakhirnya Masa Pajak yang bersangkutan sepanjang belum dibebankan sebagai biaya dan belum dilakukan pemeriksaan. Misalnya, faktur pajak diterima oleh PKP Pembeli BKP atau Penerima JKP pada minggu terakhir bulan ketiga setelah bulan pembuatan faktur pajak (faktur pajak atas penyerahan BKP tanggal 15 Juni 2018 diterima oleh pembeli BKP pada tanggal 22 Agustus 2018). Pajak masukannya belum dilaporkan dalam SPT Masa 
PPN Mei, Juni, Juli, Agustus 2018. Pada tanggal 2 September 2018, dilakukan pemeriksaan SPT Masa PPN bulan Maret sampai dengan Juli 2018.

Pada saat pemeriksaan ditemukan faktur pajak tertanggal 15 Juni 2018 yang belum dilaporkan baik dalam SPT Masa PPN Juni maupun SPT Masa PPN Juli. Dengan demikian pajak masukan itu tidak dapat dikreditkan. Bagi yang melampaui waktu 3 (tiga) bulan, pengkreditan pajak masukan tersebut dapat dilakukan melalui pembetulan SPT Masa PPN yang bersangkutan dan belum dilakukan pemeriksaan. Apabila sudah dilakukan pemeriksaan, berdasarkan Pasal 8 Ayat (1) UU KUP, tidak dapat dilakukan pembetulan SPT Masa PPN sehingga pajak masukan yang tercantum pada faktur pajak yang terkait, tidak dapat dikreditkan.

Berdasarkan Pasal 9 Ayat (8) huruf i pengkreditan pajak masukan tidak dapat diberlakukan bagi pengeluaran untuk perolehan Barang Kena Pajak atau Jasa Kena Pajak yang pajak masukannya tidak dilaporkan dalam SPT Masa PPN, yang diketemukan pada waktu dilakukan pemeriksaan. Pemeriksaan pajak pada dasarnya dilakukan untuk menguji kepatuhan pemenuhan kewajiban perpajakan serta untuk tujuan lain terkait dengan berbagai kewajiban perpajakan yang diperlukan dalam rangka tertib administrasi perpajakan. Wajib Pajak dalam peraturan perpajakan di Indonesia, diberikan suatu kepercayaan untuk menghitung, menyetor, dan melaporkan pajaknya sendiri (self assessment system). Pengujian kebenaran dan kepatuhan Wajib Pajak dilakukan dengan pemeriksaan.

Menurut Fidel, sistem pemungutan pajak tersebut mempunyai arti dipercayakan kepada wajib pajak sendiri dan melaporkan secara teratur jumlah pajak yang terutang dan yang telah dibayar sesuai dengan ketentuan yang berlaku. Kepatuhan pajak merupakan pelaksanaan atas kewajiban untuk menyetor dan melaporkan pajak yang terutang sesuai dengan ketentuan perpajakan. Kepatuhan yang diharapkan adalah kepatuhan yang sukarela bukan kepatuhan yang dipaksakan. Untuk meningkatkan kepatuhan sukarela dari wajib pajak diperlukan adanya keadilan dan keterbukaan dalam menerapkan peraturan perpajakan dan pelayanan yang baik dan cepat terhadap wajib pajak. ${ }^{18}$

${ }^{18}$ Fidel, Pembahasan Undang-Undang No. 28/2007 Tentang Ketentuan Umum dan Tata Cara Perpajakan, (Jakarta: Penerbit Amparo, 2007), hal. 6 
Pelaksanaan pemeriksaan dalam rangka untuk menguji kepatuhan pemenuhan kewajiban perpajakan Wajib Pajak dilakukan dengan menelusuri kebenaran surat pemberitahuan, pembukuan atau pencatatan, dan pemenuhan kewajiban perpajakan lainnya dibandingkan dengan keadaan atau kegiatan usaha sebenarnya dari Wajib Pajak. Salah satu bagian dari tata cara pemeriksaaan adalah mengatur tentang kewajiban menyampaikan surat pemberitahuan hasil pemeriksaan kepada wajib pajak untuk hadir dalam pembahasan hasil akhir temuan hasil pemeriksaan kepada Wajib Pajak. Di samping itu, memberikan kesempatan kepada Wajib Pajak untuk hadir dalam pembahasan akhir temuan hasil pemeriksaan dalam batas waktu yang ditentukan.

Menurut Ilyas dan Burton, prinsip self-assessment tersebut pada dasarnya memiliki makna sebagai berikut: ${ }^{19}$

1. agar semua Wajib Pajak bersifat aktif di dalam melaksanakan kewajiban perpajakannya tanpa perlu menunggu adanya surat ketetapan pajak yang akan dikeluarkan oleh petugas pajak (fiskus);

2. penghitungan jumlah pajak yang dibayar untuk sementara dianggap sebagai perhitungan menurut ketentuan yang berlaku;

3. fiskus memiliki kewenangan untuk melakukan penghitungan jumlah pajak yang telah dilaporkan Wajib Pajak sepanjang fiskus memiliki data bahwa Wajib Pajak belum melaksanakan penghitungannya dengan benar.

Setelah Wajib Pajak selesai dilakukan pemeriksaan pajak oleh pemeriksa pajak serta telah dilakukan proses pembahasan akhir antara Wajib Pajak dengan pemeriksa pajak, maka tindakan selanjutnya yang akan dilakukan oleh Direktur Jenderal Pajak adalah menerbitkan produk hukum berupa Surat Ketetapan Pajak. Salah satu Surat Ketetapan Pajak yang berhubungan dengan perbuatan hukum di atas adalah Surat Ketetapan Pajak Kurang Bayar (SKPKB). Pasal 13 Ayat (1) huruf a UU KUP mengatur bahwa SKPKB diterbitkan dalam hal-hal apabila berdasarkan hasil pemeriksaan atau keterangan lain pajak yang terutang tidak atau kurang dibayar. Wajib Pajak harus membayar jumlah kekurangan pajak dalam SKPKB ditambah dengan sanksi administrasi.

${ }^{19}$ Wirawan B. Ilyas, Richard Burton, Manajemen Sengketa Dalam Pungutan Pajak, (Jakarta: Penerbit Mitra Wacana Media, 2012), hal. 19 
Berbagai macam sanksi administrasi yang diatur dalam UU KUP adalah denda, bunga, maupun kenaikan. Denda umumnya lebih ringan dibandingkan dengan sanksi bunga dan sanksi bunga juga jauh lebih ringan dibandingkan sanksi kenaikan. Namun demikian, ada pula ketentuan sanksi denda yang dinilai memberatkan Wajib Pajak misalnya sanksi denda 50\% (lima puluh persen) dan $100 \%$ (seratus persen) dalam hal upaya keberatan maupun banding ditolak. Pengenaan sanksi pajak di dalam UU KUP menjadi bagian yang tidak terpisahkan yang dikenakan kepada semua Wajib Pajak yang terbukti bersalah melanggar ketentuan perundang-undangan perpajakan. Secara garis besar, pengenaan sanksi perpajakan terbagi dua, yaitu sanksi administrasi karena Wajib Pajak melanggar ketentuan yang bersifat administratif. Kedua, sanksi pidana karena Wajib Pajak melanggar ketentuan-ketentuan pidana.

Wajib pajak umumnya dikenakan saksi administrasi karena melanggar hal-hal seperti tidak atau terlambat menyampaikan Surat Pemberitahuan Tahunan maupun Surat Pemberitahuan Masa. Selain itu, Wajib Pajak terlambat membayar besarnya pajak terutang ke bank sesuai batas waktu yang ditentukan. Sanksi pidana umumnya diterapkan kepada Wajib Pajak yang melanggar ketentuan yang dikualifikasikan sebagai tindak pidana pajak. Sanksi pidana diterapkan karena adanya unsur kealpaan atau unsur kesengajaan yang dapat menimbulkan kerugian pada pendapatan Negara.

Akibat hukum adalah akibat yang ditimbulkan dari adanya suatu perbuatan hukum. Perbuatan yang dilakukan Wajib Pajak dengan mengkreditkan pajak masukan dengan pajak keluaran padahal pengkreditan itu tidak dapat dilakukan. Perbuatan inilah yang menimbulkan akibat hukum. Wajib Pajak yang dimaksud di sini adalah PKP. Akibat hukum yang timbul terhadap Wajib Pajak yang melampaui batas waktu yang diperkenankan untuk mengkreditkan pajak masukan dengan pajak keluaran adalah selain membayar jumlah pajak yang tidak atau kurang dibayar, masih ditambah dengan pengenaan sanksi pajak.

Akibat hukum yang timbul terhadap Wajib Pajak yang melampaui batas waktu yang diperkenankan untuk mengkreditkan pajak masukan dengan pajak keluaran adalah sanksi bunga dan kenaikan. Sanksi bunga diatur dalam Pasal 9 Ayat (2A) UU KUP yang mengatur bahwa pembayaran atau penyetoran pajak 
yang terutang yang dilakukan setelah tanggal jatuh tempo pembayaran atau penyetoran pajak dikenai sanksi administrasi berupa bunga sebesar 2\% (dua persen) per bulan yang dihitung dari tanggal jatuh tempo pembayaran sampai dengan tanggal pembayaran, dan bagian dari bulan dihitung penuh satu bulan. Sanksi administrasi kenaikan yang diatur dalam Pasal 13 Ayat (3) huruf c UU KUP sebesar 100\% (seratus persen) dari PPN yang tidak atau kurang dibayar.

\section{KESIMPULAN DAN SARAN}

\section{Kesimpulan}

Berdasarkan uraian tersebut di atas dapat disimpulkan hal-hal sebagai berikut:

1. Regulasi pengkreditan pajak masukan dengan pajak keluaran dalam masa pajak yang tidak sama yang diatur dalam Pasal 9 Ayat (9) UU PPN hanya mengakomodir dalam hal faktur pajak yang diterima tidak melampaui jangka waktu 3 (tiga) bulan. Justru, bagian penjelasan pasal ini yang mengakomodir jangka waktu lebih dari 3 (tiga) bulan. Ditinjau dari pembentukan peraturan perundang-undangan, penjelasan suatu pasal tidak boleh membuat norma baru karena bertentangan dengan Butir 177 Lampiran Undang-Undang Nomor 12 Tahun 2011 Tentang Pembentukan Peraturan Perundang-undangan. Pasal 9 Ayat (9) dan Penjelasannya juga dikategorikan tidak memenuhi asas kejelasan rumusan dalam pembentukan peraturan perundang-undangan yang baik. Setiap peraturan perundang-undangan harus memenuhi persyaratan teknis penyusunan peraturan perundang-undangan, sistematika dan pilihan kata atau terminologi, serta bahasa hukumnya jelas dan mudah dimengerti sehingga tidak menimbulkan berbagai macam interpretasi dalam pelaksanaannya. Pasal 9 Ayat (9) dan Penjelasannya juga tidak mencerminkan asas ketertiban dan kepastian hukum yang berarti bahwa setiap materi muatan peraturan perundang-undangan harus mewujudkan ketertiban dalam masyarakat melalui jaminan kepastian hukum.

2. Akibat hukum yang timbul terhadap wajib pajak yang melampaui batas waktu yang diperkenankan untuk mengkreditkan pajak masukan dengan pajak keluaran adalah selain membayar jumlah pajak yang tidak atau kurang dibayar, masih 
ditambah dengan pengenaan sanksi administrasi, yaitu bunga dan kenaikan. Sanksi bunga diatur dalam Pasal 9 Ayat (2A) UU KUP sebesar 2\% (dua persen) per bulan yang dihitung dari tanggal jatuh tempo pembayaran sampai dengan tanggal pembayaran. Sanksi administrasi kenaikan yang diatur dalam Pasal 13 Ayat (3) huruf c UU KUP adalah 100\% (seratus persen) dari PPN yang tidak atau kurang dibayar.

\section{Saran}

Ditinjau dari pembentukan peraturan perundang-undangan di Indonesia, maka dapat disarankan hal-hal sebagai berikut:

a. Seharusnya segera memperbaiki sistematika UU PPN yang sekarang, yakni dengan mereformasi Pasal 9 Ayat (9) yang sekarang dipindah menjadi Pasal 9 Ayat (8). Kemudian Penjelasan Pasal 9 Ayat (9) yang memperbolehkan pengkreditan pajak masukan dalam hal faktur pajak yang diterima terlambat melampaui jangka waktu 3 (tiga) dengan cara pembetulan SPT Masa PPN menjadi Pasal 9 Ayat (8a). Materi Pasal 9 Ayat (8) yang sekarang dipindah menjadi Pasal 9 Ayat (9).

b. Jika dimungkinkan, maka sebaiknya UU PPN tidak lagi menggunakan perubahan tetapi dicabut dan diganti dengan penomoran undang-undang yang baru. 


\section{DAFTAR PUSTAKA}

\section{Buku}

Ayza, Bustamar, 2017, Hukum Pajak Indonesia, Depok: Penerbit Kencana

Ilyas, Wirawan B, Richard Burton, 2011, Hukum Pajak Edisi 5,Jakarta: Salemba Empat

, 2012, Manajemen Sengketa Dalam Pungutan Pajak, Jakarta: Penerbit Mitra Wacana Media

Farida, Maria, 2007, Ilmu Perundang-undangan (1), Yogyakarta: Kanisius

Farouq, M, 2018, Hukum Pajak di Indonesia, Jakarta: Prenada Media Grup

Fidel, 2007, Pembahasan Undang-Undang No. 28/2007 Tentang Ketentuan Umum dan Tata Cara Perpajakan, Jakarta: Penerbit Amparo

Modeong, Supardan, Zudan Arif Fakrulloh, 2005, Legal Drafting Berporos Hukum Humanis Partisipatoris, Jakarta: PT Perca

Siahaan, Marihot Pahala, 2006, Bea Meterai di Indonesia, Jakarta: PT. Raja Grafindo Persada

Soekanto,Soerjono, 2006, Pengantar Penelitian Hukum, cet. 3Jakarta: UI Press

----------, Soerjono, Sri Mamudji, 2011,Penelitian Hukum Normatif Suatu Tinjauan Singkat, Jakarta: PT Raja Grafindo Persada

Sukardji,Untung, 2010Undang-Undang PPN 1984 Setelah Perubahan Ketiga Dengan Undang-Undang Nomor 42 tahun 2009 Komentar Pasal Demi Pasal, Jakarta: PT. Raja Grafindo Persada

---------, Untung, 2015,Pajak Pertambahan Nilai, Jakarta: PT. Raja Grafindo Persada

Yani, Ahmad, 2013, Pembentukan Peraturan Perundang-Undangan yang Responsif, Jakarta: Penerbit Konpress

\section{Peraturan Perundang-undangan}

Undang-Undang Nomor 42 Tahun 2009 Tentang Perubahan Ketiga Atas Undang-Undang Nomor 8 Tahun 1983 Tentang Pajak Pertambahan Nilai Barang dan Jasa dan Pajak Penjualan Atas Barang Mewah 
Undang-Undang Nomor 6 Tahun 1983 Tentang Ketentuan Umum dan Tata Cara Perpajakan Sebagaimana Telah Beberapa Kali Diubah Terakhir Dengan Undang-Undang Nomor 16 Tahun 2009 